\title{
PELAKSANAAN PEMBELAJARAN PENDIDIKAN JASMANI ADAPTIF BAGI ANAK CEREBRAL PALSY DI SEKOLAH DASAR PENYELENGGARA PENDIDIKAN INKLUSIF
}

\author{
Oleh: \\ Johandri Taufan ${ }^{1}, \operatorname{Ardisal}^{2}$, Damri $^{3}$ \\ ${ }^{123}$ Universitas Negeri Padang, Indonesia \\ Email: johandri.taufan@fip.unp.ac.id
}

\begin{abstract}
ABSTRAK
Penelitian ini memiliki latar belakang dari hambatan fisik dan motorik anak cerebral palsy yang mempengaruhi hambatan pada aspek intelektual, bahasa, sosial, emosi, psikologis dan kemampuan dalam melakukan aktivitas sehari-hari. Salah satu upaya pendidikan dalam memberikan penanganan khusus bagi anak cerebral palsy yakni melalui pembelajaran bina gerak yang terdapat pada pembelejaran pendidikan jasmani adaptif. Dalam pendidikan jasmani adaptif bagi cerebral palsy guru perlu mengakui bahwa aspek psikologis dari situasi kelas sama dan bahkan lebih penting daripada tujuan substantif pendidikan jasmani. Disamping itu guru perlu memiliki cara-cara kreatif dalam pengajaran agar dapat memotivasi anak. Jenis penelitian yang dipergunakan yaitu penelitian deskriptif kualitatif. Ada beberapa aspek yang akan dibahas meliputi perencanaan pembelajaran jasmani adaptif oleh guru penjas, serta sarana dan prasarana yang digunakan dalam pembelajaran.
\end{abstract}

Kata Kunci: kemampuan gerak, cerebral palsy, jasmani adaptif, inklusif

\section{PENDAHULUAN}

Beberapa permasalahan yang muncul dalam implementasi pendidikan inklusif di Indonesia utamanya berhubungan dengan layanan pendidikan bagi peserta didik berkebutuhan khusus di sekolah. Adanya hambatan dan gangguan yang dialamai oleh peserta didik berkebutuhan khusus atau yang dikenal dengan anak berkebutuhan khusus menjadikan mereka mengalami keterbatasan bahkan tidak mampu mengikuti beberapa kegiatan pembelajaran salah satunya adalah pembelajaran olahraga. Sehingga dalam rangka mengaktualisasikan pemberian layanan pendidikan dengan kualitas yang sama pada semua peserta didik, dalam pendidikan jasmani untuk peserta didik berkebutuhan khusus perlu dilakukan penyesuaian (adaptasi).

Pelaksanaan pendidikan jasmani yang disesuaikan dengan jenis dan kebutuhan khusus peserta didik selanjutnya disebut sebagai pendidikan jasmani adaptif. Dalam kurikulum pendidikan khusus 2013 sudah memuat mata pelajaran pendidikan jasmani, namun masih memerlukan model penjas adaptif secara teknis bagi peserta didik berkebutuhan khusus baik 


\section{DRAFT PROSIDING}

disekolah khusus maupun di sekolah hambatan fisik dan motorik. Peserta didik penyelenggara pendidikan inklusif.

Pendidikan jasmani atau olahraga yang dengan cerebral palsy yang memang jelas-jelas ketidakmampuan pada motoriknya yang diadaptasi dan dimodifikasi sesuai kebutuhan jenis kelainan dan tingkat kemampuan peserta didik berkebutuhan khusus merupakan salah satu faktor yang sangat menentukan keberhasilan penjas adaptif. Penjas adaptif merupakan suatu sistem penyampaian layanan yang bersifat menyeluruh (komperehensif) dan dirancang untuk mengetahui dan menemukan masalah peserta didik berkekbutuhan khsusu. Adapun ciri-ciri dari program penjas adaptif antara lain: 1) Program penjas adaptif disesuaikan dengan jenis dan karakteristik peserta didik berkebutuhan khusus. 2) Program pembelajaran penjas adaptif bertujuan membantu dan mengkoreksi kelainan yang disandang oleh peserta didik disesuaikan dengan kebutuhan khusus peserta didik berkebutuhan khusus. 3) Program Pengajaran penjas adaptif dilakukan untuk mengembangkan dan meningkatkan kemampuan jasmani peserta didik berkebutuhan khusus.

Pada kenyataannya peserta didik berkebutuhan khusus memiliki kebutuhan yang lebih besar akan gerak. Seperti dikatan oleh beberapa ahli, bahwa pendidikan jasmani harus menjadi program utama dari pendidikan luar biasa secara keseluruhan, karena menjadi dasar atau fondasi bagi peningkatan fungsi tubuh yang diperlukan untuk peserta didik berkebutuhan khusus, salah satunya cerebral palsy yang merupakan bagian dari peserta didik dengan diakibatkan rusaknya otak. Pendidikan jasmani dapat memberikan sumbangan kepada anakanak cerebral palsy.

Program pendidikan jasmani harus spesifik dan keterampilan harus diajarkan dalam pola-pola yang baik, mulai dari gerak-gerak yang paling sederhana dan bertahap ke gerakgerak yang lebih kompleks. Sebelum guru memberikan pembelajaran pendidikan jasmani adaptif kepada siswa, guru harus mengetahui tentang kondisi siswa tersebut antara lain kemampuan gerak anak, komunikasinya, perawatan diri, dan bagaimana anak menggunakan alat bantu.

Penelitian ini dilaksanakan di Sekolah penyelenggara pendidikan inklusif. Pendidikan inklusif merupakan sebuah pendekatan yang melihat bagaimana mengubah sistem pendidikan agar dapat merespon dan menerima keberagaman peserta didik, dengan tujuan guru dan siswa merasa nyaman dalam keberagaman, dan melihat keberagaman sebagai suatu tantangan dan pengayaan dalam lingkungan belajar, karena keberagaman bukanlah suatu masalah yang harus ditakuti. Adapun proses menuju sekolah penyelenggara pendidikan inklusif ini tidaklah mudah. Dalam pelaksanaannya dibutuhkan perjuangan dan tingkat kesabaran yang cukup tinggi, karena tidak serta merta guru, komite dan siswa 


\section{DRAFT PROSIDING}

maupun orang tua menerima keputusan tersebut (Taufan \& Mazhud, 2016)

Berdasarkan grandtour yang peneliti lakukan di salah satu sekolah dasar penyelenggara pendidikan inklusif, terdapat peserta didik berkebutuhan khusus dengan hambatan fisik dan motorik dengan jenis cerebral palsy. Peserta didik cerebral palsy tersebut mengalami keterbatasan dalam gerak sehingga sering kali dalam pembelajaran olahraga tidak diikut sertakan. Kemampuan gerak yang dimiliki peserta didik cerebral palsy tersebut masih sangat rendah, sehingga perlu dilatih agar kemampuan gerak yang dimilik peserta didik cerebral palsy tersebut semakin baik dan meningkatkan. Dalam pendidikan jasmani adaptif bagi cerebral palsy guru perlu mengakui bahwa aspek psikologis dari situasi kelas sama dan bahkan lebih penting daripada tujuan substantif pendidikan jasmani. Disamping itu guru perlu memiliki cara-cara kreatif dalam pengajaran agar dapat memotivasi anak.

\section{METODE PENELITIAN}

Jenis penelitian yang dipergunakan yaitu penelitian deskriptif kualitatif. Menurut Arikunto (2006) "penelitian deskriptif tidak dimasukkan untuk menguji hipotesis tertentu, tetapi hanya menggambarkan "apa adanya" tentang suatu variabel, gejala atau keadaan". Sejalan dengan hal tersebut penelitian deskriptif (descriptive research) adalah "metodologi penelitian yang digunakan untuk meneliti pada suatu kondisi objek alamiah (Sugiyono, 2005)

Subjek dalam penelitian adalah sesuatu yang dijadikan responden dalam penelitian. Subjek pada penelitian ini adalah peserta didik dengan cerebral palsy. Sumber data utama penelitian yang bersifat deskriptif kualitatif ini adalah semua yang terkait kedalam pembelajaran pendidikan jasmani adaptif bagi peserta didik cerebral palsy serta guru bidang studi terkait.

Berdasarkan jenis penelitian dan subjek penelitian yang telah ditetapkan, maka menurut Sugiyono (2005) teknik pengumpulan data merupakan langkah yang paling strategis pada penelitian yang akan dilakukan, akan ada data yang perlu untuk dikumpulkan yang disesuaikan dengan kebutuhan penelitian dan untuk menjawab pertanyaan yang ada pada penelitian. Pengumpulan data dilakukan langsung oleh peneliti sendiri secara langsung kelapangan untuk mendapatkan data yang digunakan dalam penelitian ini meliputi : Kegiatan observasi ini dilaksanakan dalam rangka melihat keadaan proses pelaksanaan pembelajaran pendidikan jasmani adaptif di Sekolah Dasar, sehingga adanya kesinambungan antara pembelajaran yang dilakukan pada saat teori dengan keadaan lingkungan yang sebenarnya.

Dalam mendapatkan data ini penulis melakukan wawancara dengan guru bidang studi olahraga sehubungan dengan segala sesuatu pelaksanaan pembelajaran meliputi diantaranya metode apa yang digunakan guru 


\section{DRAFT PROSIDING}

dalam mengajar serta metode yang paling disenangi peserta didik dalam belajar. Dokumentasi ini berupa rekaman yang diambil pada saat melakukan studi pendahuluan berlangsung. Untuk menguji kebenaran atau keabsahan data, dapat dilakukan dengan caracara sebagai berikut:

Perpanjangan keikutsertaan peneliti sangat menentukan dalam pengumpulan data. Keikutsertaan ini memerlukan perpanjangan keikutsertaan peneliti pada latar penelitian. Ketekunan pengamatan bertujuan menemukan proses pelaksanaan pembelajaran pendidikan jasmani adaptif bagi peserta didik cerebral palsy.

Audit dengan teman sejawat bertujuan untuk memeriksa kelengkapan dan ketelitian yang dilakukan sehingga timbul keyakinan bahwa sesuatu yang dilaporkan tentang pelaksanaan pembelajaran penjas adaptif tepat mencapai kebenaran yang diharapkan.

Trianggulasi dilakukan untuk mengecek keabsahan data dengan memanfaatkan sesuatu yang lain diluar data, dengan demikian trianggulasi dimaksudkan membandingkan hasil observasi dengan hasil wawancara yang dilakukan pada pembelajaran penjas adaptif.

\section{HASIL PENELITIAN}

Dalam pendeskripsian awal hasil penelitian ini, peneliti mengambil data meliputi observasi berbentuk catatan lapangan, wawancara dan studi dokumentasi. Selanjutnya data yang akan di deskripsikan berkenaan dengan permasalahan diajukan dalam fokus penelitian.

Berdasarkan kisi-kisi yang telah dirancang hasil peneliti adapun di deskripsikan sebagai

berikut :

\section{Perencanaan RPP penjas adaptif bagi peserta didik cerebral palsy}

a. Penyusunan Program Mengajar

Berdasarkan hasil pengamatan dan wawancara yang peneliti lakukan, dari penjelasan yang disampaikan responden penelitian, bahwasanya RPP yang disusun oleh guru olahraga mengacu kepada kurikulum 2013. Didalam K13 terdapat standar kompetensi, kompetensi dasar, indikator, tujuan, materi pelajaran, metode, media dan evaluasi. Perencanaan RPP inipun di modifikasi agar peserta didik cerebral palsy dapat mengikuti kegiatan pembelajaran. RPP yang disusun meliputi indikator seperti meremas, mengangkat, mengayun dan melepas pada pengembangan gerak tangan. Pada tubuh indikator yang dikembangan diantaranya meneku, meliyuk, dan meregang.

b. Langkah-langkah Pembelajaran

Berdasarkan hasil pengamatan dan wawancara dengan responden guru olahraga terkait langkah-langkah yang dilakukan guru dalam proses belajar mengajar (PBM) di luar kelas, khususnya pada mata pelajaran olahraga. Dari 


\section{DRAFT PROSIDING}

pengamatan peneliti selama melakukan penelitian didapati bahwa pelaksanaan atau memulai pembelajaran dengan ekplorasi yang diberikan kepada siswa. Sementara itu, dari penjelasan yang disampaikan responden penelitian, bahwasanya langkah- langkah pembelajaran yang dilakukan guru penjas di lapangan selalu di mulai dengan eskplorasi untuk memancing pengetahuan siswa sebelumnya dan mengetahui sejauh mana siswa sudah menguasai materi pembelajaran. Kemudian guru masuk pada kegiatan elaborasi dengan menjelaskan materi ajar sesuai dengan RPP dan melakukan konfirmasi bersamasama dengan siswa

c. Penggunaan Metode Pembelajaran Pengamatan peneliti mengenai pelaksanaan pembelajaran olahraga oleh guru penjas juga melihat metode apa yang digunakan guru dalam menyajikan materi pelajaran. Dari pengamatan peneliti selama melakukan penelitian didapati bahwa guru penjas menggunakan berbagai macam metode pembelajaran ketika menyajikan materi ajar kepada siswa. Mulai dari metode penugasan, demonstrasi, ceramah dan drill. Sementara itu, dari penjelasan yang disampaikan responden penelitian, bahwasanya metode-metode yang digunakan divariasikan agar siswa tidak merasa bosan sehingga tujuan pembelajaran dengan mudah dicapai

d. Penilaian Hasil/Evaluasi

Penilaian dilakukan tidak hanya untuk mengungkap hasil belajar ranah kognitif tetapi juga mengungkap hasil belajar ranah afektif dan psikomotor.Selain itu penilaian yang dilakukan harus memiliki azas keadilan yang tinggi. Maksudnya, peserta didik diperlakukan sama sehingga tidak merugikan salah satu atau sekelompok peserta didik yang dinilai. Dalam hal evaluasi ini guru melkaukan evaluasi dari beberapa aspek baik itu tes tulis dan prakteknya sehingga kegiatan penilaian ini lebih akurat.

e. Kerjasama dengan Guru Pembimbing Khusus (GPK)

Kerjasama guru penjas dengan GPK di sini juga menjadi fokus penelitian bagi peneliti. GPK merupakan pendamping dalam rangka menunjang perkembangan akademis bagi ABK. Sebagaimana aspek penting yang terdapat dalam sistem pendidikan inklusif yaitu guru berkualifikasi dan mengerti kondisi anak. Untuk itu diharapkan dengan keberadaan GPK dapat membantu guru bidang studi dalam mengembangkan program pembelajaran yang sesuai dengan kebutuhan peserta didik. Adanya kerjasama dengan GPK dalam pembelajaran penjas adaptif ini sangat membantu terutama dalam meningkatkan 


\section{DRAFT PROSIDING}

kemampuan gerak peserta didik cerebral palsy.

2. Sarana dan Prasarana dalam Pelaksanaan Pembelajaran Pendidikan Jasmani Adaptif

Dalam pelaksanaan pembelajaran pendidikan jasmani adaptif, diperlukannya sarana dan prasarana yang cukup sehingga menunjang pembelajaran tersebut. Pihak sekolah sendiri harus bisa memberikan sarana dan prasarana yang memadai agar pembelajaran berlangsung dengan baik. Diantara usaha yang dilakukan dalam meningkatkan kemampuan gerak peserta didik cerebral palsy tersebut adalah dengan memanfaatkan media dan peralatan sederhana yang dimiliki sekolah. Banyak alaalat yang dapat dimodifikasi sehingga bagi peserta didik cerebral palsy dapat juga menggunakan alat-alat tersebut. Diantara yang dilakukan guru olahraga untuk meningkatan kemampuan gerak adalah menggunakan bola-bola kecil. Dengan bolabola kecil ini peserta didik cerebral palsy dapat dilatih gerakan-gerakannya. Seperti bermain melempar bola, menangkap bola, mengayunkan bola dan mengelindingi bola.

\section{PEMBAHASAN}

Berdasarkan hasil penelitian tentang pelaksanaan pembelajaran pendidikan jasmani adaptif dalam meningkatkan kemampuan gerak peserta didik cerebral palsy yang diperoleh dari hasil observasi, wawancara dan studi dokumentasi terhadap proses tersebut, maka selanjutnya peneliti akan melakukan pembahasan berkaitan dengan teori yang relevan kemudian dikaitkan dengan fokus penelitian yang peneliti lakukan. Ada beberapa aspek yang akan dibahas yang kemudian akan dideskripsikan meliputi perencanaan pembelajaran jasmani adaptif oleh guru penjas, serta sarana dan prasarana yang digunakan dalam pembelajaran.

Aspek perencanaan akan dilihat dalam pelaksanaan pembelajaran berupa rancangan pembelajaran (RPP) yang dibuat oleh guru penjas. Hal ini sesuai dengan pendapat Abdoellah (1996) bahwa pendidikan jasmani adalah sebuah mata pelajaran akademik sama seperti mata pelajaran matematika dan ilmuilmu sosial. Peserta didik diwajibkan untuk berpatisipasi atau mengambil mata pelajaran pendidikan jasmani seperti mata pelajaran lainnya. Guru bertanggung jawab membuat rencanan pelajaran yang berisikan pernyataan yang jelas tentang tujuan perilaku, aktivitas pelajaran, teknik-teknik memberi rangsang dan prosedur penilaian. Berdasarkan pengamatan peneliti, guru penjas dan GPK bekerja sama ketika proses mengajar (PBM) maupun di luar PBM. Dalam PBM bentuk kerjasama guru penjas dan GPK yaitu membantu siswa autisme $\mathrm{X}$ agar dapat mengikuti pelajaran dengan tenang dan fokus memperhatikan. Jika pembelajaran olahraga tidak ada masalah berarti GPK hanya 


\section{DRAFT PROSIDING}

melihat dari kejauhan saja. Dan pembelajaran dilanjutkan dengan guru penjas.

\section{Kesimpulan}

Dapat disimpulkan untuk mendapatkan hasil yang baik dalam pelakasanaan pembelajaran perlu adanya perencanaan pembelajaran sera adanya sarana dan prasarana yang mendukung terlaksananya kegaitan belajar dan mengajar. Dengan adanya Perencanaan pembelajaran yang baik, maka kita akan lebih mudah mengarahkan kegiatan belajar peserta didik terutama peserta didik cerebral palsy. Aspek perencanaan akan dilihat dalam pelaksanaan pembelajaran berupa rancangan pembelajaran (RPP) yang dibuat oleh guru penjas. Guru bertanggung jawab membuat rencanan pelajaran yang berisikan pernyataan yang jelas tentang tujuan perilaku, aktivitas pelajaran, teknik-teknik memberi rangsang dan prosedur penilaian.

\section{REFERENSI}

Arikunto, Suharsimi. (2006). Manajemen Penelitian. Jakarta: PT. Rineka Cipta

Moleong, J. L. (2012). Metodologi Penelitian Kualitatif. Bandung: PT Remaja Rosdakarya

Sugiyono. (2005). Memahami Penelitian Kualitatif. Bandung: Alfabeta.

Taufan, J., \& Mazhud, F. (2016). KebijakanKebijakan Kepala Sekolah Dalam Penyelengaraan Pendidikan Inklusif Di Sekolah X Kota Jambi. Jurnal Penelitian Pendidikan, 14(1).

Tarigan, B. (2008). Modul Pendidikan Jasmani Adaptif. Bandung: Fakultas Pendidikan
Olahraga Dan Kesehatan Universitas Pendidikan Indonesia. 
DRAFT PROSIDING 